\title{
PENINGKATAN KEMAMPUAN MOTORIK HALUS ANAK MELALUI \\ METODE PEMBERIAN TUGAS DALAM KEGIATAN MERONCE DENGAN MEDIA BAHAN ALAM \\ DI KELOMPOK B TK AL FALAH KOTA JAMBI
}

\author{
HELMIWATI \\ TK Pertiwi I Kota Jambi \\ Email: helmiwati61@gmail.com
}

\begin{abstract}
ABSTRAK
Tujuan penelitian ini adalah untuk mengembangkan kemampuan motorik halus melalui kegiatan meronce. Latar belakang masalah dalam penelitian ini adalah pembelajaran meronce masih belum tercapainya target sesuai dengan kriteria ketuntasan pembelajaran $80 \%$ disebabkan oleh pembelajaran yang kurang menarik minat belajar anak.

Hasil dari penelitian dapat disimpulkan bahwa pembelajaran motorik halus dengan meronce menggunakan media alam dapat memotivasi dan meningkatkan hasil belajar anak di Kelompok B TK Al Falah Kota Jambi. Hal ini dapat dilihat dalam Prasiklus, hasil yang dicapai anak yang Anak mampu mengerjakan sendiri tanpa bantuan guru (Tuntas) $8 \%$, sedang anak yang Anak mampu mengerjakan sendiri dengan sedikit bantuan guru (Cukup) 12\%, Anak dalam mengerjakan selalu meminta bantuan guru / anak yang tidak mau mengerjakan tugas (Belum Tuntas) $80 \%$.

Siklus I dengan hasil yang dicapai anak yang Anak mampu mengerjakan sendiri tanpa bantuan guru (Tuntas) 16\%, sedang anak yang Anak mampu mengerjakan sendiri dengan sedikit bantuan guru (Cukup) 36\%, Anak dalam mengerjakan selalu meminta bantuan guru / anak yang tidak mau mengerjakan tugas (Belum Tuntas) $48 \%$.

Dalam siklus II peneliti menggunakan bahan alam berupa pelepah daun singkong, hasilnya dapat dilihat bahwa kemampuan belajar anak yang meningkat secara signifikan hasil belajar anak dari siklus I terhadap siklus II, anak anak yang anak mampu mengerjakan sendiri tanpa bantuan guru (Tuntas) $80 \%$, sedang anak yang mampu mengerjakan sendiri dengan sedikit bantuan guru (Cukup) 8\%, Anak dalam mengerjakan selalu meminta bantuan guru / anak yang tidak mau mengerjakan tugas (Belum Tuntas) menjadi $12 \%$
\end{abstract}

Kata kunci : Motorik halus, meronce, media alam

\section{A. PENDAhuluan}

\section{Latar Belakang}

Pendidikan anak usia dini merupakan pendidikan tahap awal di jenjang formal karena anak-anak belajar sambil bermain. Guru adalah orang yang paling 
dipercaya oleh anak-anak sehingga di dalam pembelajaran diharapkan guru menggunakan media yang nyata dan mudah dipahami oleh anak-anak dalam mengajar. Guru diharapkan mampu untuk berkreasi dalam mengembangkan imajinasi serta kreatif yang dimilikinya.

Anak usia dini sering juga disebut dengan golden age atau usia emas karena rentang usia ini anak mengalami pertumbuhan dan perkembangan yang sangat pesat dalam berbagai aspek. Kenapa Periode ini disebut sebagai masa keemasan? Sebab, pada masa itu otak anak sedang mengalami pertumbuhan dan perkembangan yang sangat pesat, dan otak merupakan kunci utama bagi pembentukan kecerdasan anak.

Periode ini dimulai sejak janin dalam kandungan hinga usia 6 (enam) tahun. Pada masa ini, pertumbuhan dan perkembangan otak anak mencapai $80 \%$ dari otaknya di masa dewasa kelak. Artinya diatas periode ini, perkembangan otak hanya $20 \%$ saja. Perkembangan anak pada tahun tahun pertama sangat penting dan akan menentukan kualitasnya dimasa depan.

Anak adalah individu yang berbeda unik, dan memiliki karakteristik sendiri sesuai dengan tahapan usianya. Oleh karena itu upaya-upaya pengembangan anak usia dini hendaknya dilakukan melalui belajar dan melalui bermain (Learning through games).

Masa kanak-kanak merupakan salah satu masa terpenting dalam rentang kehidupan manusia. Sebab, ia menjadi pijakan fase-fase selanjutnya dalam proses pendidikan dan pembinaan pribadi.Kehidupan pada masa anak merupakan suatu periode yang disebut dengan periode kritis ataupun periode sensitif dimana kualitas perangsangan harus diatur sebaik-baiknya, tentunya memerlukan intervensi baik dari guru maupun orang tua. Hal ini diperkuat dengan penelitian yang dilakukan oleh Blooms dalam Wijana mengemukakan bahwa separuh potensi manusia sudah terbentuk ketika berada dalam kandungan sampai usia 4 tahun, dan 30\% terbentuk pada usia 4-8 tahun.

Berdasarkan uraian tersebut dapat dipahami bahwa masa usia dini merupakan periode yang penting dalam rentang kehidupan manusia. Oleh karena itu rentang usia dini merupakan saat yang paling tepat untuk mengembangkan 
berbagai potensi dan kemampuan anak, sehingga pengembangan potensi secara terarah pada usia tersebut akan berdampak pada kehidupan masa depannya. Salah satunya dengan pemberian rangsangan pendidikan sejak usia dini.

Anak yang mendapat pendidikan sejak usia dini akan dapat meningkatkan kesehatan serta kesejahteraan fisik dan mental, sehingga akan lebih mampu untuk mandiri dan mengoptimalkan berbagai potensi yang dimilikinya. Potensi yang dimiliki oleh anak perlu dikembangkan secara optimal. Karena pada masa ini merupakan periode yang sangat kritis dalam tahap perkembangan manusia.

Hasil penelitian mengungkapkan bahwa sampai usia 4 tahun, tingkat kapabilitas kecerdasan anak telah mencapai 50\%. Pada usia 8 tahun mencapai $80 \%$ dan sisanya sekitar $20 \%$ diperoleh pada saat anak berusia 8 tahun ke atas. Berdasarkan pengamatan, perkembangan anak di TK Al Falah Kota Jambi Kota Jambi Kelompok B ditemukan adanya kendala pada kegiatan motorik halus yaitu sebagian besar anak masih kesulitan dalam melakukan kegiatan motorik halus khususnya melipat atau origami. Ada beberapa anak yang enggan untuk melakukan kegiatan motorik halus ada juga yang menangis sehingga hasil belajar anak kurang optimal.

Pembelajaran di Taman Kanak-kanak memiliki bermacam-macam tema yang akan diajarkan kepada anak, yang tertuang dalam RKM dan RKH. Pendidikan Taman Kanak-kanak bertujuan untuk membantu meletakkan dasar ke arah perkembangan sikap, pengetahuan, keterampilan, daya cipta yang diperlukan oleh anak didik dalam menyesuaikan diri dengan lingkungannya dan untuk pertumbuhan serta perkembangan selanjutnya. Pendidikan dini bagi anak usia 4-6 tahun merupakan masa peka bagi anak. Anak mulai sensitif untuk menerima berbagai upaya perkembangan seluruh potensinya.

Masa peka adalah masa terjadinya pematangan fungsi-fungsi fisik dan psikis yang siap merespon stimulasi yang diberikan oleh lingkungan. Anak memiliki kesempatan untuk bereksplorasi menemukan, mengekspresikan perasaan berkreasi, dan belajar secara menyenangkan. Kemampuan motorik halus Anak Melalui Anak Melalui Metode Pemberian Tugas dalam kegiatan Meronce Dengan Media Bahan Alam Di TK Al Falah Kota Jambi pada anak merupakan salah satu 
aspek psikis manusia yang sangat penting untuk dipupuk dan dikembangkan karena dengan motorik halus siswa dapat menemukan cara-cara menilai sesuatu dengan tepat dan dapat menghadapi, mengolah serta mengawasi stimulasi sesuai dengan tuntutan jaman. Menurut Permendiknas No 58 Tahun 2009, pendidikan belajar sambil bermain sangatlah penting untuk meningkatkan motorik halus anak di dalam belajar. Melalui belajar dan bermain diharapkan dapat mengembangkan segenap potensi yang dimiliki anak-anak yaitu moral dan nilai-nilai agama, sosial, emosional, dan kemandirian, berbahasa, kognitif, fisik/motorik dan seni.

Masa kanak-kanak merupakan salah satu masa terpenting dalam rentang kehidupan manusia. Sebab, ia menjadi pijakan fase-fase selanjutnya dalam proses pendidikan dan pembinaan pribadi.Kehidupan pada masa anak merupakan suatu periode yang disebut dengan periode kritis ataupun periode sensitif dimana kualitas perangsangan harus diatur sebaik-baiknya, tentunya memerlukan intervensi baik dari guru maupun orang tua. Hal ini diperkuat dengan penelitian yang dilakukan oleh Blooms dalam Wijana mengemukakan bahwa separuh potensi manusia sudah terbentuk ketika berada dalam kandungan sampai usia 4 tahun, dan $30 \%$ terbentuk pada usia 4-8 tahun.

Berdasarkan uraian tersebut dapat dipahami bahwa masa usia dini merupakan periode yang penting dalam rentang kehidupan manusia. Oleh karena itu rentang usia dini merupakan saat yang paling tepat untuk mengembangkan berbagai potensi dan kemampuan anak, sehingga pengembangan potensi secara terarah pada usia tersebut akan berdampak pada kehidupan masa depannya. Salah satunya dengan pemberian rangsangan pendidikan sejak usia dini.

Anak yang mendapat pendidikan sejak usia dini akan dapat meningkatkan kesehatan serta kesejahteraan fisik dan mental, sehingga akan lebih mampu untuk mandiri dan mengoptimalkan berbagai potensi yang dimilikinya. Potensi yang dimiliki oleh anak perlu dikembangkan secara optimal. Karena pada masa ini merupakan periode yang sangat kritis dalam tahap perkembangan manusia.

Hasil penelitian mengungkapkan bahwa sampai usia 4 tahun, tingkat kapabilitas kecerdasan anak telah mencapai 50\%. Pada usia 8 tahun mencapai $80 \%$ dan sisanya sekitar $20 \%$ diperoleh pada saat anak berusia 8 tahun ke atas. 
Berdasarkan pengamatan, perkembangan anak di TK Al Falah Kota Jambi Kelompok B ditemukan adanya kendala pada kegiatan motorik halus yaitu sebagian besar anak masih kesulitan dalam melakukan kegiatan motorik halus khususnya melipat atau origami. Ada beberapa anak yang enggan untuk melakukan kegiatan motorik halus ada juga yang menangis sehingga hasil belajar anak kurang optimal.

Hasil belajar anak ini dapat berupa angka huruf dan hasil belajar yang dicapai kurang memenuhi target. Dari 19 anak yang dapat melakukan kegitan meronce tanpa dibantu hanya 5 anak. Ketika guru sedang menerangkan langkah untuk melipat, anak ditanya apakah sudah bisa atau belum, hampir semua anak menjawab sudah. Tetapi ketika diminta mengerjakan ternyata masih banyak yang kesulitan.

Piaget dan Vigotsky dalam Badru mengemukakan bahwa pentingnya aktivitas bermain sebagai sarana untuk pendidikan anak, terutama yang berkaitan dengan pengembangan kapasitas berpikir. Mereka berpendapat bahwa aktifitas bermain juga dapat menjadi akar bagi perkembangan prilaku moral.Seorang pakar pendidikan mengatakan bahwa "pendidikan akan berhasil melalui gerakan dan melalui gerakan terwujudlah pendidikan".

Dunia anak adalah dunia bermain. Kegiatan bermain merupakan bagi anak usia dini adalah sesuatu yang sangat penting dalam perkembangan kepribadiannya. Bermain bagi seorang anak tidak sekedar mengisi waktu, tetapi media baginya untuk belajar. Dengan bermain, seorang anak dapat mengembangkan kemampuan motorik.

Undang-undang Republik Indonesia tentang Sistem Pendidikan Nasional Nomor 20 Tahun 2013 pasal 1 dan 3 disebutkan bahwa pasal 1 pendidikan anak usia dini merupakan suatu upaya pembinaan yang ditujukan kepada anak sejak lahir sampai usia delapan tahun yang dilakukan melalui pemberian rangsangan pendidikan untuk membantu pertumbuhan dan perkembangan jasmani maupun rohani agar anak memiliki kesiapan dalam memasuki pendidikan lebih lanjut. Proses pendidikan yang dilalui haru bermutu untuk memantapkan karakter anak 
sejak dini sampai dewasa dengan tahapan pendidikan selanjutnya yang bermutu.(Sumarto, 2018)

Menurut Susarno, Lamijan Hadi dan Roesminingsih "Pendidikan dalam arti luas berarti suatu proses untuk mengembangkan semua aspek kepribadian manusia, yang mencakup pengetahuannya, nilai serta sikapnya dan keterampilannya. Pendidikan pada hakikatnya akan mencakup kegiatan mendidik, mengajar dan melatih.

Secara yuridis istilah anak usia dini di Indonesia ditujukan kepada anak sejak lahir sampai usia enam tahun. Sedangkan menurut Bredekamp dan Copple mengemukakan bahwa pendidikan anak usia dini mencakup berbagai program yang melayani anak sejak lahir sampai dengan usia delapan tahun yang dirancang untuk meningkatkan perkembangan intelektual, sosial, emosional, bahasa dan fisik anak.

PAUD merupakan suatu upaya pembinaan yang dilakukan melalui pemberian rangsangan pendidikan untuk membantu pertumbuhan dan perkembangan jasmani dan rohani anak agar anak memliki kesiapan dalam memasuki pendidikan lebih lanjut.

Perkembangan dan pertumbuhan anak sangat perlu dipahami sebab setiap anak tidaklah sama, setiap anak itu unik dan semuanya secara individual, menawarkan kontribusi yang berharga bagi kebudayaan manusia. Semakin baiknya gerakan motorik halus anak membuat anak dapat berkreasi seperti merobek, menggunting kertas, dengan hasil guntingan yang lurus, menggambar sederhana, menjahit, menganyam kertas, menajamkan pinsil dengan rautan pinsil.

Namun tidak semua anak memiliki kematangan untuk menguasai kemampuan ini pada tahap yang sama. Kegiatan melipat dalam pembelajaran keterampilan motorik halus merupakan media pembelajaran yang bersifat interaktif dan tidak terkesan monoton yang bertujuan untuk melatih kelenturan otot-otot jari anak dan untuk menghindarkan rasa jenuh.

Berdasarkan hasil observasi awal di Taman Kanak-kanak Al Falah Kota Jambi, ditemukan anak yang perkembangan keterampilan motoriknya kurang optimal seperti kurang luwes kemampuan gerak atau kemampuan motorik halus 
anak masih rendah, anak belum mampu melakukan kegiatan yang menggunakan otot-otot kecil. Hal tersebut disebabkan karena guru cenderung monoton saat kegiatan pembelajaran, serta media dan kegiatan yang disediakan guru kurang menarik, teknik serta metode yang diberikan guru kurang tepat dikelas. Hal tersebut sangat berpengaruh pada fisik motorik anak.

Pendapat ini sejalan dengan Peraturan Menteri Pendidikan dan Kebudayaan Republik Indonesia Peraturan Menteri No. 137 tahun 2014 tentang standar isi Tingkat Pencapaian Perkembangan Anak untuk anak usia 5 sampai 6 sebagai berikut diantaranya: Melakukan kegiatan yang menunjukkan anak mampu terampil menggunakan tangan kanan dan kiri dalam berbagai aktivitas misal: mengancingkan baju, menali sepatu, melipat, menggambar, merobek, menggunting dan menempel.

Hetherington dan parke, Selama rentang usia sekolah anak lebih mengambarkan perilaku seperti menolong dan peduli terhadap orang lain dalam kegiatannya mengamati orang lain. Mereka pada umumnya juga mengenali kebutuhan orang lain bahkan ketika mereka sendiri sedang terlibat dalam suatu masalah.

Berdasarkan Tingkat Pencapaian Perkembangan Anak Usia Dini yang berisi kaidah pertumbuhan dan perkembangan anak sejak lahir sampai dengan usia enam tahun yaitu meliputi aspek perkembangan nilai agama dan moral, fisik motorik, bahasa, sosial emosional, serta seni. Aspek-aspek yang dimiliki tersebut perlu mendapat rangsangan dan perhatian yang baik.

Dalam Standar isi tentang Tingkat pencapaian perkembangan anak usia 56 tahun dapat dilihat pada tabel di bawah ini:

STPAA perkembangan motorik halus anak pada usia 5-6 tahun

\begin{tabular}{|l|c|}
\hline Lingkup Perkembangan & Tingkat pencapaian perkembangan \\
\cline { 2 - 2 } & Usia 5-6 tahun \\
\hline $\begin{array}{l}\text { Mengguna- kan anggota } \\
\text { tubuh untuk } \\
\text { pengembangan motorik } \\
\text { kasar dan halus }\end{array}$ & $\begin{array}{l}\text { Melakukan kegiatan yang menunjukkan } \\
\text { anak mampu terampil menggunakan tangan } \\
\text { kanan dan kiri dalam berbagai aktivitas }\end{array}$ \\
\hline
\end{tabular}




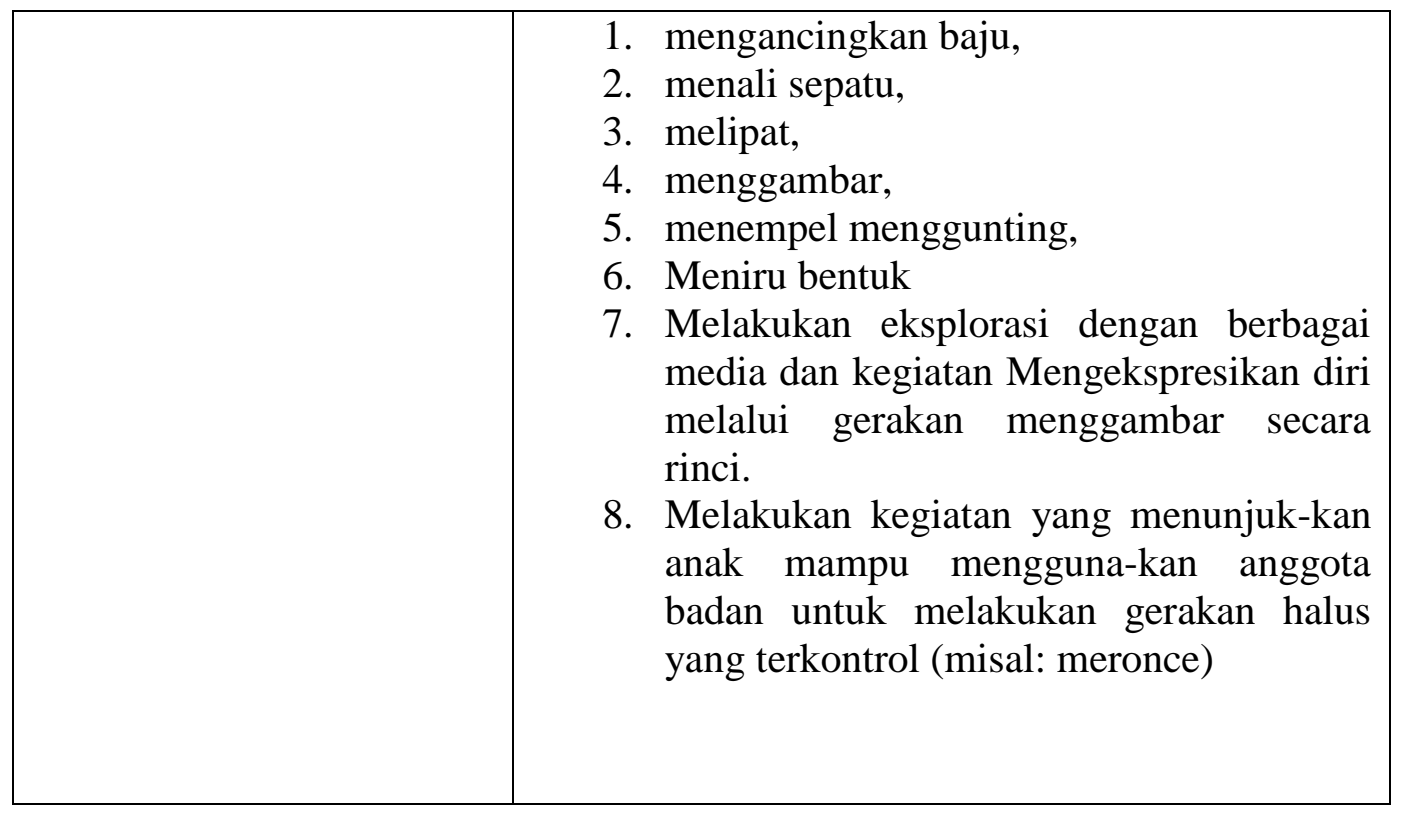

Dari Tabel STPPA di atas dapat dilihat Lingkup perkembangan dari aspek sosial emosionaladalah kesadaran diri, Rasa tanggung jawab untuk diri sendiri dan orang lain serta anak diharapkan memiliki Perilaku Prososial nantinya.

Berdasarkan Grand Tour hasil pengamatan yang dilakukan pada saat proses pembelajaran di TK Al falah Kota Jambi ditemukan siswa kurang termotivasi terhadap proses pembelajaran yang diajarkan oleh guru sehingga proses pengembangan motorik anak autis menjadi tidak optimal. Hal ini terlihat masih ada anak yang dalam proses pembelajaran berlangsung kurang bersemangat.

Mengingat perkembangan emosi anak sangat pesat pada usia dini, maka perkembangan motorik anak melalui bermain dengan berbagai macam permainan dapat mengembangkan kemampuan dasar motorik halus pada anak. Kegiatan pembelajaran yang optimal adalah situasi ketika anak-anak dapat berinteraksi antara satu dengan yang lainnya untuk mencapai tujuan. Salah satu usaha yang dapat dilakukan adalah dengan memahami bagaimana siswa belajar, apakah perilaku belajar telah berlangsung pada diri anak.

Metode pemberian tugas melalui kegiatan meronce merupakan salah satu upaya untuk meningkatkan kemampuan motorik halus pada anak. Pemberian tugas merupakan pekerjaan tertentu yang sengaja harus dikerjakan oleh anak yang 
mendapat tugas. Metode pemberian tugas berbantuan media bahan alam merupakan salah satu upaya yang dapat diterapkan untuk meningkatkan motorik halus anak. Anak dapat belajar kreatif, melatih kelenturan serta keterampilan tangan, ketelitian, kerapian yang dihubungkan dengan koordinasi pusat pusat syaraf otot dan mata. Selain itu melalui metode pemberian tugas ini anak dapat melatih ketepatan atau keterampilan, melatih ingatan serta melatih penalaran anak.

Melihat manfaat yang diberikan inilah sehingga metode pemberian tugas merupakan metode yang tepat digunakan dengan begitu apa yang menjadi daya ciptanya akan terwujud sekaligus secara tidak sengaja terjadi peningkatan motorik halus. Berdasarkan observasi di TK Al Falah Kota Jambi diketahui bahwa dalam kegiatan meronce anak-anak kurang semangat dalam menyusun media manikmanik, pipet, dan bahan roncean yang disediakan oleh guru.

Anak-anak terlihat hanya sekedar menyusun saja tanpa memperhatikan pola maupun warna yang mereka susun, mereka hanya menyusun sesuka hatinya asalkan sudah tersusun saja tanpa peduli hasil karyanya tersebut rapi atau tidak asalkan media yan 3 yang baru dan mampu membuat sesuatu yang berbentuk hasil karya, pada intinya kegiatan ini dilakukan oleh anak-anak dengan cara bermain sambil belajar. Kondisi saat ini di Kelompok B TK Al Falah Kota Jambi adalah kurangnya minat dan pengembangan kegiatan meronce.

Metode yang digunakan selama ini masih konvensional dengan cara penjelasan satu arah oleh guru kepada murid. Sehingga siswa kurang berperan aktif untuk mengikuti proes pembelajaran khususnya meronce. Oleh karena itu melalui penelitian ini bermaksud mengkaji dengen metode baru meronce menggunakan bahan alam diharakan mampu meningkatkan kreativitas dan peran aktif anak dalam kegiatan meronce.

Mengingat masalah tersebut sangat penting, maka tujuan yang ingin dicapai adalah untuk mengetahui peningkatan kreativitas meronce setelah penerapan metode pemberian tugas berbantuan media bahan alam pada anak kelompok B Tk Al falah Kota Jambi. 
Berdasarkan uraian permasalahan diatas, maka penulis tertarik untuk membuat penelitian yang berjudul “ Meningkatkan Kemampuan Motorik halus Anak Melalui Kegiatan Melipat Pada anak Kelompok B TK Al Falah Kota Jambi”

\section{Perumusan Masalah}

Apakah kegiatan meronce dapat meningkatkan kemampuan motorik halus anak Kelompok B di TK Al Falah Kota Jambi tahun ajaran 2018/2019?

\section{Tujuan Penelitian}

Penelitian ini bertujuan mengetahui peningkatkan kemampuan Motorik halus anak melalui metode pemberian tugas dalam kegiatan meronce dengan media alam di TK Al Falah kota Jambi Tahun ajaran 2018/2019.

\section{B. LANDASAN TEORI}

\section{Kemampuan Motorik Halus Anak}

Kemampuan Motorik Halus anak adalah kesanggupan dalam suatu bidang tertentu yang berhubungan dengan gerakan yang melibatkan bagian-bagian tubuh tertentu saja dan dilakukan oleh otot-otot kecil seperti ketrampilan menggunakan jari-jari tangan dan gerakan pergelangan tangan, maka kemampuan motorik halus anak perlu diasah sedemikian rupa agar suatu saat nanti otot-otot jari tangan anak lebih kuat dan mampu untuk digunakan berbagai aktivitas yang berhubungan dengan motorik.

Tujuan pengembangan motorik halus anak di usia 4 sampai 6 tahun adalah:

1. Mampu menggerakkan anggota tubuh yang berhubungan dengan gerak jari jemari seperti kesiapan menggambar, menulis, memanipulasi benda-benda.

2. Mampu mengkoordinasikan indra mata dan aktivitas tangan.

3. Mampu mengendalikan emosi dalam beraktivitas motorik halus.

4. Mampu mengembangkan kemampuan motorik halus yang berhubungan dengan ketrampilan gerak kedua tangan. 


\section{Media pembelajaran}

Pemakaian media pembelajaran dalam proses belajar mengajar dapat membangkitkan keinginan dan minat yang baru, membangkitkan motivasi dan rangsangan kegiatan belajar, dan bahkan pengaruhpengaruh psikologis terhadap siswa. Hujair AH. Sanaky (2009: 6) mengemukakan bahwa fungsi media pembelajaran adalah merangsang pembelajaran dengan :

a. Menghadirkan obyek sebenarnya dan obyek yang langkah,

b. Membuat duplikasi dari obyek yang sebenarnya,

c. Membuat konsep abstrak ke konsep konkret,

d. Memberi kesamaan presepsi,

e. Mengatasi hambatan waktu, tempat, jumlah, dan jarak,

f. Menyajikan ulang informasi secara konsisten

g. Memberi suasana belajar yang tidak tertekan, santai dan menarik, sehingga dapat mencapai tujuan pembelajaran.

Terselenggaranya suatu pembelajaran tidak terlepas dari peran media pembelajaran. Media pembelajaran merupakan suatu alat bantu pembelajaran yang digunakan sebagai penghubung antara guru dan siswa agar pembelajaran dapat tersampaikan dengan baik. Rahyubi (2012: 244) menyatakan "media adalah perantara atau pengantar pesan dari pengirim kepada penerima pesan”.

Pendapat yang serupa juga dikemukakan oleh Aqib (2013: 50) yang menyatakan bahwa "media pembelajaran adalah segala sesuatu yang dapat digunakan untuk menyalurkan pesan dan merangsang terjadinya proses belajar pada si pembelajar (siswa)". Melalui media pembelajaran pesan yang ingin disampaikan oleh guru lebih mudah untuk tersampaikan, sehingga memudahkan siswa untuk mencapai tujuan pembelajaran dengan baik.

Berdasarkan pendapat yang telah dikemukakan oleh beberap ahli, peneliti mengambil kesimpulan bahwa media pembelajaran adalah segala sesuatu yang dapat digunakan untuk menyalurkan pesan, merangsang pikiran, perasaan, perhatian, dan kemauan siswa sehingga dapat mendorong proses belajar dan mencapai tujuan pembelajaran yang telah ditetapkan. Jenis media secara luas 
dibagi menjadi dua yaitu, pilihan media tradisional dan pilihan media teknologi mutakhir.

Peranan media pembelajaran sangat diperlukan dalam suatu kegiatan belajar mengajar. Melalui bermain anak akan belajar. Bermain merupakan suatu kegiatan atau tingkah laku yang dilakukan anak secara sendirian atau berkelompok dengan menggunakan alat atau tidak menggunakan alat untuk mencapai tujuan tertentu. Jadi bermain ada yang dapat dilakukan secara sendiri dan ada juga yang dilakukan secara berkelompok.

Berdasarkan uraian tentang fungsi media pembelajaran di atas dapat ditegaskan bahwa fungsi media pembelajaran terkait dengan meningkatkan kemampuan motorik halus anak autis adalah penggunaan media pembelajaran kreasi kirigami dapat memberikan suasana belajar yang tidak tertekan, santai, dan menarik sehingga dapat mencapai tujuan yang diinginkan.

Dalam memilih media pembelajaran perlu disesuaikan dengan kebutuhan, situasi dan kondisi masing-masing siswa. Pemakaian media pengajaran dalam proses belajar mengajar dapat membangkitkan motivasi dan rangsangan kegiatan belajar, dan bahkan membawa pengaruh-pengaruh psikologis terhadap siswa.

\section{METODE PENELITIAN}

\section{Jenis Penelitian}

Penelitian ini termasuk penelitian tindakan kelas (PTK) atau dalam bahasa inngris sering disebut Classroom Action Research (CAR) yaitu suatu pencermatan terhadap kegiatan belajar berupa sebuah tindakan yang sengaja dimunculkan dan terjadi dalam sebuah kelas secara bersama (Suharsimi Arikunto, 2007).

\section{Jenis Data}

Data dalam penelitian ini ada dua macam yaitu sumber data primer dan sumber data sekunder. Sumber data primer yaitu data yang peneliti peroleh dari pengamatan di kelompok B TK Al Falah Kota Jambi Semester II tahun ajaran 2018/2019, sedangkan sumber data sekunder adalah sumber data yang diperoleh dari hasil pengamatan teman sejawat melalui subyek yang sama. 


\section{Setting Penelitian}

Penelitian ini dilaksanakan pada anak kelompok B di TK Al Falah Kota Jambi Kota Jambi tahun ajaran 2018/2019. Penelitian akan dilakukan pada tahun ajaran 2018/2019,

\section{Metode Pengumpulan}

Data Metode pengumpulan data pada penelitian ini sebagai berikut:

1. Wawancara

2. Observasi

3. Dokumentasi

\section{HASIL PENELITIAN DAN PEMBAHASAN}

Tindakan siklus I selesai peneliti melakukan refleksi dan evaluasi. Hal ini dilakukan sebagai acuan pada siklus II. Aspek indikator anak dapat meningkat, setelah dilakukan refleksi dan evaluasi maka diadakan tindakan siklus II. Pada pelaksanaan siklus II sudah mengalami peningkatan jika dibandingkan sebelum tindakan dan pada tindakan.

Melalui kegiatan melipat ini dapat dilihat bagaimana peningkatan prestasi anak mulai dari sebelum penelitian, hingga penelitian berakhir setelah dilakukan tindakan yang dilakukan yaitu dengan kegiatan melipat dalam proses pembelajaran. Aspek indikator anak pada siklus I peneliti mentargetkan tingkat pencapaian prosentase $\geq 40 \%$. Hal ini belum dikatakan meningka karena prosentase rata-rata kurang dari yang ditargetkan yaitu $26.3 \%$.

Dilakukan refleksi dan evaluasi hasil tersebut dirasa kurang maksimal, kemudian dirancang untuk melakukan siklus II yang nantinya diharapkan dapat lebih meningkat pada aspe indikator anak dan untuk meyakinkan hasil yang diperoleh. Tindakan siklus II selesai peneliti melakukan refleksi dalam evaluasi.

Siklus II ini peneliti mentargetkan tingkat pencapaian prosentase $\geq 50 \%$ sedangkan prosentase rata-rata dalam 1 kelas mencapai $54.7 \%$ hal ini sudah bisa dikatakan meningkat. Hal ini dilakukan sebagai acuan pada siklus III. Aspek indikator anak dapat meningkat, setelah dilaukan refleksi dan evaluasi maka dilakukan tindakan siklus III pada pelaksanaan. 
Siklus III sudah mengalami peninkatan jika dibandingkan sebelum tindakan dan pada tindakan I dan II. Proses kegiatan berlangsung kwalitas kegiatan pada tiap siklusnya mengalami peningkatan secarabertahap dan pada akhirnya dapat meningkat aspek indikator anak pada siklus I dan II, hasilnya kurang maksimal. Hal ini disebabkan anak masih kurang memperhatikan penjelasan dari peneliti dan anak merasa jenuh. Pembelajaran tindakan kelas pada siklus ke III berjalan lebih baik, jika dibandingkan dengan tindakan siklus I dan II.

Hasil yang dicapai mengalami peningkatan karena dirasa cukup hasil yang diperoleh dari siklus III yaitu $88.8 \%$ melebihi target $80 \%$ meninkatkan aspek indikator dalam meningkatkan kemampuan motorik halus anak melalui kegiatan melipat. Secara keseluruhan penerapan kegiatan melipat ini berpengaruh positif baik terhadap proses pembelajaran dapat meningkat.

Aspek indikator dalam meningkatkan motorik halus anak juga dapat membantu anak dalam meronce yang dapat dilihat pada aspek indikator pada kegiatan melipat. Berdasarkan hasil observasi diketahui bahwa motorik halus setiap anak berbeda. Hal ini terbukti masih ada anak yang belum mencapai target yang ditentukan peneliti.

Hal ini tidak menjadi masalah mengingat motorik halus anak berbedabeda, selain itu rata-rata prosentase dalam kelas sudah meningkat yaitu sebesar 88.8\% . Pada siklus I peneliti mentargetkan tingkat pencapaian prosentase $\geq 40 \%$ akan tetapi dari hasil pelaksanaan siklus I masih ada 10 anak yang belum mampu mencapai target.

Hal ini disebabkan karena dari 10 anak tersebut merupakan anak-anak yang memiliki daya konsentrasi yang rendah, sulit diberitahu dan kemandiriannya kurang. Tri Cahyono yang memiliki prosentase terndah merupakan anak yang memiliki kesulitan dalam belajar, terlalu pemalu dan tidak mandiri masih ditunggu ibunya di dalam kelas.

Pada siklus II peneliti mentargetkan tingkat prosentase $\geq 50 \%$. Jumlah anak yang belum mencapai target yang ditentukan oleh peneliti yaitu 7 anak, 
sedangkan pada siklus III peneliti mentargetkan prosentase $80 \%$. Jumlah anak yang belum mencapai target yang ditentukan adalah 2 anak.

\section{E. KESIMPULAN, IMPLIKASI, SARAN}

\section{Kesimpulan}

Peningkatan kemampuan motorik halus anak merupakan salah satu yang dipengaruhi oleh pembelajaran motorik halus anak yang diterapkan dalam kegiatan melipat. Kegiatan melipat ini dapat meningkatkan kemampuan motorik halus karena penerapannya melalui kegiatan melipat. Selain itu dalam kegiatan melipat ini peneliti kenalkan bentuk-bentuk lipatan lebih dari satu lipatan.

Pada kegiatan melipat ini juga fleksibel karena penerapannya dapat dipadukan dengan bernyanyi, demonstrasi, penugasan, unjuk kerja dan tanya jawab. Kesimpulan dari analisis dan pembahasan tentang ;penelitian telah dijabarkan di atas yaitu kegiatan melipat dapat meningkatkan kemampuan motorik halus anak kelompok B di TK Al Falah Kota Jambi.

Hal ini terbukti dengan adanya peningkatan prosentase kemampuan motorik halus anak sesuai indikator kinerja yang telah ditentukan dari sebelum tindakan sampai dengan siklus III. Yakni sebelum tindakan 26.3\%, siklus I mencapai 31.9\%, siklus II mencapai 54.7\% dan siklus III mencapai 88.3\%. Hasil ini melebihi target peneliti yang menmtargetkan $80 \%$ keberhasilan dari tindakan I (siklus I), tindakan II (siklus II) dan tindakan III (siklus III), dengan kegiatan yang berbeda-beda disetiap pertemuan menjadikan anak lebih kreatif 15 dan mempunyai semangat untuk mengembangkan motorik halus melalui kegiatan melipat.

\section{Implikasi}

Keberhasilan peningkatan motorik halus anak melalui kegiatan melipat memberikan sebagai berikut: 1. Dalam memberikan kegiatan melipat untuk anak usia pra sekolah hendaknya kegiatan pembelajaran yang diterapkan disesuaikan dengan karakteristik dan tahap perkembanagn anak. 2. Kegiatan melipat diterapkan untuk meningkatkan kemmapuan motorik halus anak.

\section{Saran}


Berdasarkan hasil penelitian dan kesimpulan di atas, maka dalam rangka meningkatkan kemampuan motorik halus anak melalui kegiatan melipat dapat diajukan sejumlah saran yaitu untuk:

1. Kepala TK

- Perlu adanya bimbingan kepada guru kelas agar lebih terampil dalam melatih motorik halus, agar anak lebih terampil dalam menggerakkan jari tangan untuk kelenturan, kekuatan dan koordinasi.

- Perlu adanya perhatian kepada anak dalam melatih otot-otot tangan saat meronce dengan pola, karena sebagian anak dalam meronce sesuai pola belum bisa dan sebagian besar masih banyak bimbingan atau perhatian lebih agar bisa meronce dengan bai dengan baik.

2. Kepada Guru

- Guru TK diharapkan mampu melaksanakan pembelajaran sesuai kurikulum

- Guru TK hendaknya memperhatikan karakteristik dan tahap perkembangan anak dalam memberi pembelajaran atau kegiatan.

- Guru TK harus mampu menciptakan suasana belajar yang menarik dan menyenangkan.

- Kegiatan melipat perlu diberikan secara konsisten untuk menstimulasi kemampuan motorik halus anak usia dini.

3. Kepada Orang Tua

- Sediakan waktu khusus untuk melatih motorik halus melalui kegiatan melipat kertas.

- Sabar dalam melatih motorik halus anak, jangan terlalu memaksa anak untuk bisa agar anak tidak merasa tertekan.

\section{DAFTAR PUSTAKA}

Direktoral Pendidikan Anak Usia Dini. Ditjen Pendidikan non Formal dan Informal, Pedoman Teknis Penyelenggaraan Kelompok Bermain, 2010.

Margono. 2004. Metodologi Penelitian Pendidikan. Jakarta: PT Rineka Cipta.

Permen Diknas No. 58 tahun 2009 Poerwadarminta.1994.Kamus Umum Bahasa Indonesia.Jakarta : Balai Pustaka. 
Sanjaya, Wina. 2009. Penelitian Tindakan Kelas. Jakarta: Kencana.

Sujiono. 2007. Metode Pengembangan Fisik. Jakarta: UT.

Wijaya. Rusyan.1992. Perkembangan dan Konsep Dasar Pengembangan Anak Usia Dini. Jakarta : Bumi Aksara.

Rika Ariyani, Editor Jurnal Literasiologi. Literasi Kita Indonesia. STAI Syekh Maulana Qori. Merangin Bangko.

Sumarto, S. (2018). Peran dan Kredibilitas Badan Akreditasi Nasional Sekolah/Madrasah (Ban S/M) Mewujudkan Sekolah Efektif Melalui Manajemen Mutu. Jurnal Literasiologi, 1(1), 12-12. 